\title{
Aerobic Bacteria in the Diaphragmatic Portion of Stethoscope of Medical Professionals of Tertiary Care Hospital
}

\author{
Gajendra Bham, ${ }^{1}$ Jeetendra Bhandari, ${ }^{1}$ Madan Ratna Neupane, ${ }^{1}$ Roji Dawadi, ${ }^{2}$ Prasil Pradhan \\ 'Patan Academy of Health Sciences-School of Medicine, Lagankhel, Lalitpur, Nepal.
}

\begin{abstract}
Introduction: Hospital environment is a reservoir of wide varieties of microorganisms which are frequently reported colonizing in medical equipment. Stethoscopes are essential tools and of universal use in the medical profession, which might be a source of spreading nosocomial infections. This research project was conducted with an aim to assess the presence of aerobic bacteria in the stethoscope of the medical doctors working at Patan Hospital and students ofPatan Academy of Health Sciences.
\end{abstract}

Methods: It is a cross sectional study based on structured questionnaire and sample assessment from the stethoscope of doctors and students of Patan Hospital and Patan Academy of Health Sciences. The stethescopes used by the doctors of five major departments of Patan Hospital and students of clinical years were included in this study.

Results: Total of 99 stethoscope owned by different level of professionals (positions) and different departments were examined for bacterial contamination. Out of them, 36 were found to be considerably contaminated. Single strain of bacteria was grown from a single stethoscope. Among them 34 were Gram positive and remaining were Gram negative. Out of 34 gram postive bacteria, 29 were identified as Staphylococcus aureus, six were identified as Coagulase Negative Staphylococcus and remaining were Gram positive bacilli.

Conclusions: There is presence of aerobic bacteria in diaphragmatic portion of stethoscope of medical professional of which the gram positives were the commonest.

Keywords: anaerobic bacteria; stethescope; medical professionals; patan hospital.

\section{INTRODUCTION}

Hospital environment is reservoir of wide varieties of microorganisms which are frequently reported colonizing in medical equipment. ${ }^{1-4}$ Stethoscopes might be a source of spreading nosocomial infections. ${ }^{3}$ The universal and unavoidable use of the stethoscope and its direct contact with multiple patients makes it an important potential factor in the dissemination of microorganisms from one patient to another. ${ }^{2}$

In a study conducted at Jimma University, Ethiopia, out of 176 stethoscopes examined, 151 were found to be considerably contaminated. ${ }^{1}$ Research conducted by Merinella AM et al. $^{2}$ on stehescopes of doctor and nurses has shown eleven types of bacteria, with coagulase-negative staphylococcus present on all stethoscopes and Staphylococcus aureus on

Correspondence: Jeetendra Bhandari, Patan Academy of Health Sciences-School of medicine, Lagankhel, Lalitpur, Nepal. Email: z2jeetendra@gmail.com, Phone:+977-9849599324. 
$38 \%$ of the stethoscopes. In a study conducted by Merlin MA et al. ${ }^{3}$ they have reported that MRSA was present on approximately one in three stethoscopes of professionals. In a study done by Patrick Tang HP et al. ${ }^{4}$ they have found that, stethoscope contamination rates in Emergency Department are higher in comparison to stethoscope used by health personnel of other department. This research aimed to assess presence of aerobic bacteria in stethoscope of the medical doctors and students at Patan Hospital(PH) and Patan Academy of Health Sciences (PAHS).

\section{METHODS}

It was a cross sectional study based on structured questionnaire and sample assessment from stethoscope of doctors and students of Patan Hospital and Patan Academy of Health Sciences. The study was carried out in 5 major departments of Patan Hospital- General Surgery, Medicine, Pediatrics, Gynecology and Emergency which are the departments where the stethoscope areused the most, and among the students at PAHS. Project was carried out on $13^{\text {th }}$ and $14^{\text {th }}$ of September 2015. The study included stethoscopes used by doctors working at different posts i.e Consultant, Resident, Medical Officer, Intern and Medical Student who are presently studying at PAHS- and are at clinical years. Sample size was calculated using formula "Sample size $=\left(z^{2} X p X q\right) / E^{2 "}$. Where Value of $p$ and $q$ were kept 0.5 and value of $E$ was kept 0.1 . Individuals were selected by simple random sampling method by using Microsoft Excel-2013.

The permission for conducting the research was obtained from PAHS-IRC. Informed consent was taken from each of the participant before collecting sample. The research purpose was explained to the participants and their confidentiality was maintained by coding their identity.

A set of structured questionnaire was used in this study. The questionnaire was divided into 2 parts, the demographic characteristics and three questions regarding the practice of cleaning stethoscope. Data were collected via two methods, i.e self-administered questionnaire. Samples were collected from the diaphragm of the stethoscopes with the help of sterile swab soaked in sterile normal saline. The swab was then inoculated on Blood agar and Mac Conkey agar and incubated for $24 \mathrm{hrs}$. After 24hrs, the media were examined for bacterial growth. The bacteria grown were identified using standard microbiological procedure. EPI info seven was used for data entry and SPSS was used for data analysis.

\section{RESULTS}

A total of 99 stethescopes owned by five different professionals(posts) namely Clinical Specialists (6), MD Resident (15), Medical Officer (28), Intern(8) and Medical Student (42) were examined for bacterial contamination.. These professionals were working in 5 different wards namely General Surgery (4), Pediatrics(11), Medicine(17), Gynecology(10) and Emergency(14).

\begin{tabular}{|c|c|c|c|}
\hline \multicolumn{2}{|l|}{$\begin{array}{l}\text { No } \\
\text { Yes }\end{array}$} & \multicolumn{2}{|c|}{ BacterialGrowth } \\
\hline \multirow{3}{*}{$\begin{array}{l}\text { After } \\
\text { each } \\
\text { patient }\end{array}$} & Count & 2 & 1 \\
\hline & $\begin{array}{l}\% \text { within Times } \\
\text { of cleaning } \\
\text { stethoscope }\end{array}$ & $66.7 \%$ & $33.3 \%$ \\
\hline & $\begin{array}{l}\% \text { within Bacterial } \\
\text { Growth }\end{array}$ & $3.2 \%$ & $2.8 \%$ \\
\hline \multirow{3}{*}{$\begin{array}{l}\text { Daily } \\
\text { before } \\
\text { going to } \\
\text { clinic }\end{array}$} & Count & 10 & 6 \\
\hline & $\begin{array}{l}\% \text { within Times } \\
\text { of cleaning } \\
\text { stethoscope }\end{array}$ & $62.5 \%$ & $37.5 \%$ \\
\hline & $\begin{array}{l}\% \text { within Bacterial } \\
\text { Growth }\end{array}$ & $16.1 \%$ & $16.7 \%$ \\
\hline \multirow{4}{*}{$\begin{array}{l}\text { Once a } \\
\text { week }\end{array}$} & Count & 19 & 8 \\
\hline & $\begin{array}{l}\% \text { within Times } \\
\text { of cleaning } \\
\text { stethoscope }\end{array}$ & $70.4 \%$ & $29.6 \%$ \\
\hline & $\begin{array}{l}\text { \% within Bacterial } \\
\text { Growth }\end{array}$ & $30.6 \%$ & $22.2 \%$ \\
\hline & Count & 9 & 6 \\
\hline \multirow[t]{2}{*}{$\begin{array}{l}\text { Once a } \\
\text { month }\end{array}$} & $\begin{array}{l}\% \text { within Times } \\
\text { of cleaning } \\
\text { stethoscope }\end{array}$ & $60.0 \%$ & $40.0 \%$ \\
\hline & $\begin{array}{l}\% \text { within Bacterial } \\
\text { Growth }\end{array}$ & $14.5 \%$ & $16.7 \%$ \\
\hline \multirow{3}{*}{$\begin{array}{l}\text { Once a } \\
\text { year }\end{array}$} & Count & 7 & 0 \\
\hline & $\begin{array}{l}\% \text { within Times } \\
\text { of cleaning } \\
\text { stethoscope }\end{array}$ & $100.0 \%$ & $0.0 \%$ \\
\hline & $\begin{array}{l}\% \text { within Bacterial } \\
\text { Growth }\end{array}$ & $11.3 \%$ & $0.0 \%$ \\
\hline
\end{tabular}

Out of 99 stethoscopes examined, 36(36.4\%) were considerably contaminated whereas the rest were sterile $(63.6 \%)$. While analysing the proportion, majority of stethoscopes used by surgery and Emergency Department $(50 \%)$ were contaminated followed by the stethoscopes used by Gynaecology (40\%) and relatively less contamination was observed in the stethoscopes 
used by professionals of Paediatrics.

While comparing post of doctors and students to the bacterial contamination, majority of bacterial contamination was observed in stethoscope among Medical officer (46.4\%) which was followed by Intern (37.5\%). This was followed by Medical Students and MD resident (33.3\%).Least was found in Consultant (16.7\%).

While comparing the last use of stethoscope and bacterial growth, highest bacterial growth was found in those stethoscopes which were used within 15 minutes (52.8\%)followed by stethoscope which were used more than 5 hours(33.3\%).

From $36 \quad(36.4 \%)$ contaminated stethoscope diaphragms, single strain of bacteria was grown from all stethoscopes. No mixed colonies were identified. Among them $34(94.4 \%)$ were Gram positive and remaining were Gram negative. Bacterial identification was done in which $29(80.55 \%)$ were identified as Staphylococcus aureus, 6(16.66\%) were identified as Coagulase Negative Staphylococcus (CONS) and remaining were Gram positive bacilli.

Of 99 stethoscope studied, 68(68.7\%) owner reported that they used disinfectant to clean their stethoscope. Among the respondent $19(19 \%)$ used chlorehexidine containing preparation and $49(49.5 \%)$ used spirit swab for cleaning their stethoscope. No significant relation was identified among the use of disinfectant and bacterial isolation.

\section{DISCUSSION}

Health care workers are a potential source of nosocomial infection. Among different methods of transmission of infection, transmission through medical devices occurs the most. The spread of nosocomial infection is attributed to different medical device among which stethoscope is one of them. Several studies have been done to see the presence of microorganisms in stethoscope used by the medical professionals.

Our study shows that a total of $36.4 \%$ of stethoscopes were contaminated which is not consistent with the findings of similar studies done by TekluShiferaw et al. ${ }^{1}$ at Jimma University, Ethiopia,(85.8\%). This may be due to the regular and higher rate of use of disinfectant in our study $(68 \%)$ than that by the participants in Shiferaw et al. study inwhichnon of the parcipants used disinfectants to clean the stethescope. ${ }^{1}$ However, in otherstudy done by Africa-Purino and his colleagues, they have found lower rate $(57 \%)$ of contamination. ${ }^{5}$

The results of our study reveal that stethoscopes that are utilized in daily clinical practice carry potentially pathogenic microorganisms. Our normal skin flora consist mainly gram positive bacteria which may be the reason for maximum isolates of gram positive organisms ( $94 \%)$ and less gram negative (6\%)organism. Similar findings has been reported in a study by Shiferaw et al. which shows Gram-positive isolates (78.9\%) more frequent than gram-negative isolates $(21.1 \%)$. This might also be because the lifespan of gram-negative bacteria is not more than six hours in vitro. ${ }^{6}$

Our study indicates high contamination rate of stethoscopes with potential pathogens which might cause variety of diseases. This study could identify the gram positive organisms but could not identify gram negative, gram positive bacilli and antimicrobial resistance pattern of bacteria those were isolated due to limited time frame and financial constrain.

\section{CONCLUSIONS}

There is presence of aerobic bacteria in diaphragmatic portion of stethoscope of medical professional of which the gram positives were the commonest.

\section{REFERENCES}

1. Shiferaw T, Beyene G, Kassa $T$, Sewunet T. Bacterial contamination, bacterial profile and antimicrobial susceptibility pattern of isolates from stethoscopes at Jimma University Specialized Hospital. Ann ClinMicrobio1Antimicrob. 2013;12:39.

2. Marinella MA, Pierson C, Chenoweth C. The stethoscope. A potential source of nosocomial infection? Arch Intern Med. 1997 Apr 14;157(7):786-90.

3. Merlin MA, Wong ML, Pryor PW, Rynn K, Marques-Baptista A, Perritt R, Stanescu CG, Fallon T. Prevalence of methicillinresistant Staphylococcus aureus on the stethoscopes of emergency medical services providers. PrehospEmerg Care. 2009 Jan-Mar;13(1):71-4.
4. Tang PH, Worster A, Srigley JA, Main CL. Examination of staphylococcal stethoscope contamination in the emergency department (pilot) study (EXSSCITED pilot study). CJEM. 2011 Jul;13(4):239-44.

5. Africa-Purino FC, Dy ER, Coronel R: Stethoscopes: a potential source of nosocomial infections. Phil J Microbiol Infect Dis 2000, 29(2):9-13.

6. Gastmeier P, Schwab F, Barwolf S, Ruden H, Grundmann $\mathrm{H}$ : Correlation between the genetic diversity of nosocomial pathogens and their survival time in intensive care units. J Hosp Infect 2006, 62(2):181-186. 